\title{
Isolation and Characterization of an Endopolygalacturonase from Cochliobolus sativus and a Cytological Study of Fungal Penetration of Barley
}

\author{
Ronald P. Clay, Carl W. Bergmann, and Melvin S. Fuller
}

First and second authors: Complex Carbohydrate Research Center, The University of Georgia, Athens; and third author: Department of Botany, The University of Georgia, Athens.

Accepted for publication 11 July 1997.

\begin{abstract}
Clay, R. P., Bergmann, C. W., and Fuller, M. S. 1997. Isolation and characterization of an endopolygalacturonase from Cochliobolus sativus and a cytological study of fungal penetration of barley. Phytopathology 87 : 1148-1159.

Endopolygalacturonase (EPG) of Cochliobolus sativus was produced in shake culture and purified by high-performance liquid chromatography. The enzyme had a molecular mass of 34,000 $\mathrm{Da}$, an isoelectric point in the range of 9.0 to 9.5 , exhibited endo activity, was nonglycosylated, and was inhibited by polygalacturonase-inhibiting proteins from bean, pear, and tomato. The amino terminus contained a 14 amino acid region homologous to a region at the $\mathrm{N}$ terminus of an EPG of $C$. carbonum. C. sativus EPG-specific monoclonal antibodies (MAbs) were generated. Western blot analysis confirmed the specificity of the antibodies for the EPG and detected the enzyme in an extract from Hordeum
\end{abstract}

ABSTRACT vulgare (cv. Golden Promise) leaf segments infected with $C$. sativus. Using conventional immunogold and enzyme-gold cytochemical methods, homogalacturonan, esterified pectin, and cellulose were localized in healthy and infected barley leaf epidermis at the electron microscope level. Additionally, the leaf cell wall polysaccharides recognized by purified C. sativus EPG were localized at the electron microscope level, using the purified enzyme as a primary cytochemical reagent, followed by a gold-labeled MAb specific for the enzyme. Loss of polygalacturonic acid in the vicinity of the invading pathogen was visualized cytochemically at the electron microscope level. These observations suggest the involvement of EPG during host penetration by the fungus.

Additional keywords: amino acid sequence, cytochemistry, Edman degradation, electron microscopy, ELISA, light microscopy, mass spectrometry, pectinase.
Cell wall-degrading enzymes (CWDEs), produced by plant pathogens during penetration and subsequent infection of hosts are thought to play a significant role in pathogenesis $(3,15,21,29)$. A wide range of activities are attributed to these enzymes, from enzymatic cleavage of structural host cell wall polysaccharides, in which the integrity of the cell wall barrier to pathogen entry is compromised, to more complex roles within the sphere of hostpathogen interactions, such as the release of oligosaccharides that function as "elicitors" of plant defense responses $(15,16,21,29)$. Although the importance of CWDEs to pathogenesis is widely accepted, evidence for any single enzyme being solely responsible for pathogen virulence in a given host/pathogen system has yet to emerge; rather, it appears that multiple enzymatic activities act in concert or succession to achieve successful pathogenesis (4). Accordingly, attempts to demonstrate the requirement of a given enzyme for successful pathogenesis have produced negative results. The gene responsible for the endopolygalacturonase (EPG) activity of the maize (Zea mays L.) pathogen Cochliobolus carbonum R.R. Nelson was disrupted (37), but the organism was still able to infect host tissue. Subsequently, the gene for the major extracellular $\beta$-1,4-xylanase of $C$. carbonum was disrupted (2), and likewise, the organism remained pathogenic. Although the results of these studies suggest these specific enzymes are not required for pathogenesis, studies have not addressed the contributions, in spatial or temporal terms, of these CWDEs during host penetration and infection by the wild-type pathogen. Therefore, the results provide no insight into how penetration is accom-

Corresponding author: R. P. Clay; E-mail address: rclay@ccrc.uga.edu

Publication no. P-1997-0828-02R

(C) 1997 The American Phytopathological Society plished by the mutant organisms or into the nature of the role of EPG or xylanase during penetration by wild-type fungi under normal conditions, such that successful penetration can occur in the absence of either enzyme. For example, it has not been determined whether the order in which the cell wall polysaccharides are degraded differ from that seen during penetration by the wild-type pathogen or whether penetration pegs of the mutants penetrate by a circuitous route, nor was it determined that either pectin or hemicellulose, the cell wall substrates for the enzymes disrupted in these studies, presents a barrier to the wild-type pathogen during penetration of the host. Such information is central to a meaningful evaluation of these types of gene-disruption experiments.

Preliminary microscopic observations of the C. sativus (Ito \& Kuribayashi) Drechs. ex Dastur/Hordeum vulgare L. system revealed a pronounced separation of leaf epidermal cell walls along the middle lamella during early penetration, suggesting that EPG from $C$. sativus is involved in early penetration of barley $(H$. vulgare) by this fungal pathogen (12). Because these findings did not agree with findings from the EPG gene-disruption experiment (37) from the closely related organism C. carbonum, we sought further evidence for EPG involvement in early infection of $H$. vulgare by C. sativus by applying immunological methods, including in situ immunolocalization techniques at the electron microscope level.

The current research paper describes the production, purification, and characterization of an EPG of C. sativus. We also describe the very early penetration of barley epidermis by $C$. sativus at both the light and electron microscopic levels, cytochemically localize some of the major host cell wall polysaccharides at the penetration site, and cytochemically visualize the subsequent loss of polygalacturonic acid (PGA) in the immediate vicinity of the penetrating pathogen. For these cytochemical studies, we obtained 
the antipectin monoclonal antibodies (MAbs) JIM 5 and JIM 7 and also generated MAbs to the $C$. sativus EPG. The pectic substrate of the EPG was localized in barley leaf epidermal cell walls at the electron microscopic level by a novel application of the purified enzyme and an anti-EPG MAb, confirming the localization of EPG substrate by the JIM 5 antibody. With these microscopic and cytochemical data as a baseline, future studies of the $C$. sativus/H. vulgare system that utilize enzyme-deficient mutants may provide additional insight into the necessity and contribution of EPG and other CWDEs during early host penetration.

\section{MATERIALS AND METHODS}

Fungal culture. $C$. sativus strain SB85 (18) was used to produce EPG in shake culture. For shake culture, $10^{4}$ spores from $3-$ to 4-week-old potato dextrose agar cultures (13) were inoculated into 500-ml volumes of minimal salts medium (9) containing $1 \%$ (wt/vol) citrus pectin (Sigma Chemical Co., St. Louis). The openings of the 1,000-ml flasks used for shake culture were covered with inverted $150-\mathrm{ml}$ beakers, which were covered with aluminum foil to allow greater gas exchange than conventional gauze plugs; this method yielded much faster fungal growth and EPG production while preventing contamination as efficiently as gauze plugs. Flasks were incubated on a rotary shaker at $120 \mathrm{rpm}$ at $29^{\circ} \mathrm{C}$ until cultures were ready for harvesting. The time from flask inoculation until harvest of the fungal growth medium varied from 4 to 8 days.

Enzyme purification. Soluble EPG production was monitored in shake flasks daily by viscometric and substrate-gel assays (described below). When enzyme activity peaked, the fungal mycelium was removed from the culture medium by filtering through a 45-mesh stainless-steel screen. The protein was recovered from the growth medium by precipitation with an equal volume of $100 \%$ ethanol, followed by centrifugation at $6,000 \times g$ for $10 \mathrm{~min}$. The pellet was resolubilized in $50 \mathrm{ml}$ of $20 \mathrm{mM}$ sodium acetate buffer ( $\mathrm{pH}$ 5.0), and the resultant solution was clarified by centrifugation at $6,000 \times g$ for $10 \mathrm{~min}$. The sample was diluted fourfold with $20 \mathrm{mM}$ sodium acetate buffer at $\mathrm{pH} 4.0$, applied to a 1-ml Pharmacia (Piscataway, NJ) HiTrap-SP cation-exchange column, and eluted at a flow rate of $1 \mathrm{ml} / \mathrm{min}$ with a $\mathrm{pH}$ and $\mathrm{NaCl}$ gradient (Fig. 1) ranging from $20 \mathrm{mM}$ sodium acetate ( $\mathrm{pH} 4.0$; buffer A) to $20 \mathrm{mM} N$-2-hydroxyethylpiperazine- $N^{\prime}$-2-ethanesulfonic acid $(\mathrm{pH}$ 7.5; buffer B) containing $0.3 \mathrm{M} \mathrm{NaCl}$. Peak elution was monitored by absorbance at $280 \mathrm{~nm}$. Fractions containing pectinolytic activity, as detected by the substrate-gel assay (described below), were pooled, diluted fourfold with buffer A, reloaded on the same column, and subjected to a second chromatographic separation. The lead shoulder and major peak of EPG-positive fractions, which eluted in this second chromatographic step, contained a small amount of a $12-\mathrm{kDa}$ contaminant that was removed by microdialysis in Amicon (Beverly, MA) microconcentrators, with a molecular mass cut-off of $30 \mathrm{kDa}$, resulting in preparations that were homogeneous for EPG, as determined by sodium dodecyl sulfatepolyacrylamide gel electrophoresis (SDS-PAGE). The trailing EPGpositive fractions eluting from the second chromatographic separation contained small amounts of the $12-\mathrm{kDa}$ contaminant and a $58-\mathrm{kDa}$ contaminant. EPG from these fractions was purified to homogeneity, as determined by SDS-PAGE, by a third cationexchange chromatographic separation, using a Pharmacia Mono-S cation-exchange column and the same buffer system used previously. Chromatographically purified EPG was aliquoted, frozen, and stored at $-20^{\circ} \mathrm{C}$.

Assays for pectinolytic activity. Viscometric analysis (1) was used to detect EPG activity in samples containing residual pectin, because the high background levels of reducing sugar precluded the use of a reducing sugar assay. Sodium polypectate $(3 \mathrm{ml}, 5 \%$ [wt/vol]; Sigma), $0.075 \mathrm{M}$ citrate buffer ( $4.5 \mathrm{ml}, \mathrm{pH} 5.5)$, and test supernatant $(0.5 \mathrm{ml})$ were mixed and incubated at $27^{\circ} \mathrm{C}$ prior to viscometry. Values obtained were expressed as relative viscometric activity, defined as the percent reduction of the reaction mixture viscosity compared to the viscosity of water at $27^{\circ} \mathrm{C}$. The $p$-hydroxy-benzoic acid hydrazide (PAHBAH) assay (27) for reducing sugars was used to measure the activity of purified EPG.

The semiquantitative (qualitative) substrate-gel assay consisted of placing $1 \mu \mathrm{l}$ of sample on a 0.1 -mm-thick substrate gel cast on gel backing (14) and allowing the sample to be absorbed into the gel for $5 \mathrm{~min}$. Gels were developed by exposure to $0.1 \%$ aqueous ruthenium red, revealing clear spots where EPG-positive samples had been applied. The substrate gel consisted of $0.1 \%$ sodium polypectate (Sigma) and $1 \%$ agarose in $20 \mathrm{mM}$ sodium acetate buffer at $\mathrm{pH} 5.0$; rapid clearing of this substrate under these conditions was indicative of EPG activity (14).

EPG-inhibition assay. Polygalacturonase-inhibiting proteins (PGIPs) from bean (Phaseolus vulgaris L.), pear (Pyrus communis L.), and tomato (Lycopersicon esculentum Mill.) were evaluated for their ability to inhibit $C$. sativus EPG. The assays for inhibition of $C$. sativus EPG by PGIPs were performed according to the method of Cervone et al. (11).

SDS-PAGE. SDS-PAGE was performed according to the method of Laemmeli (26), with $10 \%$ gels (10\% total acrylamide/bis-monomer concentration).

Isoelectric focusing (IEF). IEF was performed by the Pharmacia PhastSystem following the manufacturer's recommended protocol. Pharmacia PhastGel IEF 3-9 IEF gels were used. Migration of unknowns was compared to that of protein standards with known isoelectric points.

Amino acid sequencing. Amino acid sequencing was performed at the Molecular Genetics Instrumentation Facility, University of Georgia, Athens. The amino-terminal sequence of the EPG was determined by Edman degradation with $\mathrm{ABI}$ 470A or 477A protein sequencers (Applied Biosystems Division, Foster City, CA). The amino acid sequence obtained was compared to published amino acid sequences of other fungal EPGs by the University of Wisconsin Genetic Computer Group sequence analysis software package (17).

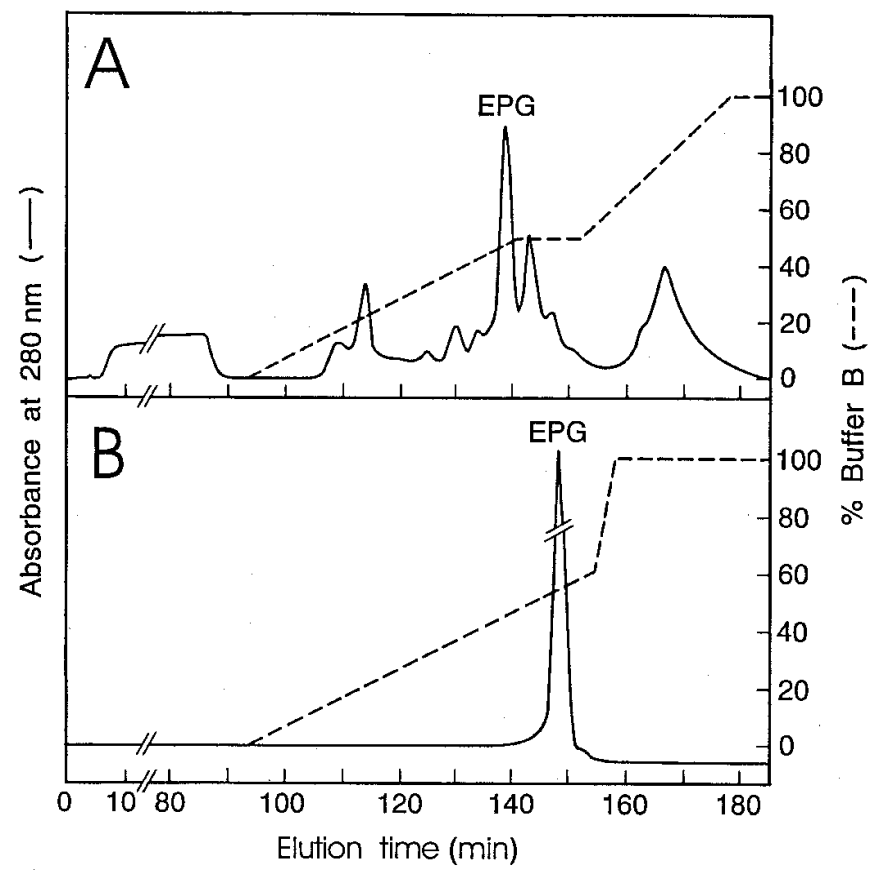

Fig. 1. A, High-performance liquid chromatography (HPLC) cation-exchange chromatography of proteins recovered by ethanol precipitation from Cochliobolus sativus growth medium containing citrus pectin as the sole carbon source. B, HPLC cation-exchange chromatography of endopolygalacturonase-containing fractions pooled from peak eluting at $47 \%$ (vol/vol) buffer B (described in text) during the initial HPLC separation shown in $\mathbf{A}$. 
MALDI-TOF-MS. The molecular weight of $C$. sativus EPG was determined by matrix-assisted laser desorption/ionization timeof-flight mass spectrometry (MALDI-TOF-MS) on a HewlettPackard (Palo Alto, CA) LDI 1700XP time-of-flight mass spectrometer. The instrument was operated at an accelerating voltage of $30 \mathrm{kV}$, an extractor voltage of $9 \mathrm{kV}$, and a pressure of $\approx 7.3 \times$ $10^{-7}$ torr. The mass range was calibrated with a $1: 1: 1$ mixture of equine heart cytochrome $\mathrm{C}$ (molecular weight $[\mathrm{MW}]=12,360$ ), equine heart myoglobin ( $\mathrm{MW}=16,950)$, and bovine serum albu$\min (\mathrm{MW}=66,465)$ to give a mass accuracy of $\approx \pm 0.1 \%$. Samples were desorbed/ionized from the probe tip with a nitrogen laser $(\lambda=$ $337 \mathrm{~nm}$ ) with a pulse width of $3 \mathrm{~ns}$ and delivering $\approx 11.9 \mu \mathrm{J}$ of energy per laser pulse. Two independent preparations of $C$. sativus EPG were analyzed. Aqueous solutions of $C$. sativus EPG were mixed with an aqueous $90 \%$ methanol solution of $33 \mathrm{mM} \alpha$ cyano-4-hydroxycinamic acid (the MALDI matrix). Approximately $1 \mu \mathrm{l}$ of each sample/matrix mixture was placed on the probe tip and vacuum crystallized. The mass spectrum was recorded over a mass to charge $(\mathrm{m} / \mathrm{z})$ range of 1 to 150,000 , with a deflector to attenuate the detected abundance of ions below 3,000 m/z. Each spectrum obtained was the average of 25 to 50 laser pulses.

Lectin analysis for presence of glycosylation. EPG was tested for the presence of carbohydrate moieties by probing a Western blot of a crude fungal extract containing the EPG with lectin-digoxigenin (DIG) conjugates (Dig Glycan Differentiation Kit, BoehringerMannhiem Biochemicals, Indianapolis, IN), including Galanthus nivalis, Sambucus niger, Datura stramonium, Maackia amurensis, and peanut (Arachis hypogea) agglutinins followed by visualization with an anti-DIG-alkaline phosphatase chromogenic system. The combination of lectins used could detect the presence of all common $\mathrm{N}$ - or $\mathrm{O}$-linked oligosaccharides. The manufacturer's recommended protocol was followed.

Deglycosylation. Attempts were made to deglycosylate the $C$. sativus EPG, both enzymatically and chemically. Enzymatic deglycosylation was attempted by incubating $10 \mu \mathrm{g}$ of EPG with $0.125 \mu \mathrm{g}$ of $N$-glycanase (Genzyme, Cambridge, MA) in $100 \mu \mathrm{l}$ of $50 \mathrm{mM}$ sodium phosphate $(\mathrm{pH} 8.5)$ for $24 \mathrm{~h}$ at $37^{\circ} \mathrm{C}$. Alternatively, $10 \mu \mathrm{g}$ of EPG was incubated with $0.1 \mu \mathrm{g}$ of endo $\mathrm{H}$ (Genzyme) in $100 \mu \mathrm{l}$ of $25 \mathrm{mM}$ sodium acetate ( $\mathrm{pH} \mathrm{6.0)}$ ) for $24 \mathrm{~h}$ at $37^{\circ} \mathrm{C}$. The reactions were terminated in a dry heating block at $100^{\circ} \mathrm{C}$ for $2 \mathrm{~min}$. The samples were centrifuged at $15,000 \times g$, and the supernatants were saved.

Chemical attempts at deglycosylation were performed by dissolving $20 \mu \mathrm{g}$ of lyophilized $C$. sativus EPG in $50 \mu \mathrm{l}$ of hydrogen fluoride containing $10 \%$ (vol/vol) anhydrous methanol. The reaction was carried out at $4^{\circ} \mathrm{C}$ for $2 \mathrm{~h}$ and was stopped by addition of ice-cold water $(200 \mu \mathrm{l})$ before lyophilization. The sample was redissolved in $200 \mu \mathrm{l}$ of water and was again lyophilized; this procedure was repeated a total of three times to ensure removal of all hydrogen fluoride. Alternatively, $20 \mu \mathrm{g}$ of lyophilized $C$. sativus EPG was dissolved in $100 \mu \mathrm{l}$ of trifluoromethanesulfonic acid, followed by addition of $5 \mu \mathrm{l}$ of anisole; all treatments were performed under a stream of nitrogen. The reaction was carried out at room temperature for $2 \mathrm{~h}$. The reaction was terminated by freezing to $-78^{\circ} \mathrm{C}$ followed by addition of $-20^{\circ} \mathrm{C}$ pyridine/diethylether $(1: 9$, $\mathrm{vol} / \mathrm{vol}$ ), yielding a fluffy white precipitate. The sample was blown to dryness under a stream of nitrogen. Pure water $(1 \mathrm{ml})$ was added to the residue in each tube, yielding a milky-white suspension that was dialyzed exhaustively against distilled water. The resulting solution was centrifuged at $15,000 \times g$, and the pellet was saved for analysis.

Production of MAbs. For the production of MAbs, chromatographically purified EPG was used in preparation of the immunogen. To prepare the immunogen, purified EPG in $50 \mathrm{mM}$ sodium acetate $(\mathrm{pH} 5.0 ; 2 \mathrm{mg} / \mathrm{ml})$ was emulsified with an equal volume of complete Freund's adjuvant (Sigma) by repeatedly forcing the mixture through a double-based needle. Female BALB/c mice initially were immunized subcutaneously with $100-\mu$ l aliquots of immunogen. One and two months after the primary immunization a boost immunization was performed by intraperitoneal injection of $50 \mu \mathrm{l}$ of immunogen produced by emulsification of EPG in $50 \mathrm{mM}$ sodium acetate (pH 5.0; $2 \mathrm{mg} / \mathrm{ml}$ ) with an equal volume of incomplete Freund's adjuvant. Seven days after the boost immunizations test bleeds were performed for titer determination. Eleven days after the second boost a final intraperitoneal boost of $25 \mu \mathrm{l}$ of purified EPG in $50 \mathrm{mM}$ sodium acetate $(\mathrm{pH} 5.0 ; 2 \mathrm{mg} / \mathrm{ml}$ ) was administered. Three days after this final boost the mouse exhibiting the highest titer was sacrificed by cervical dislocation, and the spleen was removed for subsequent fusion. Myelomas used for the fusion were SP2/0 cells (25). Cell fusion and subsequent growth and cloning of hybridomas for the production of MAbs was performed using a standard technique (20). All titer determinations and hybridoma screening were performed by enzyme-linked immunosorbent assay (ELISA). Monoclonal hybridoma fluid was aliquoted and frozen until use.

ELISA. The ELISA protocol used was performed as outlined by Pratt et al. (31) and used chromatographically purified EPG as the adsorbed antigen. Wells of 96-well microtiter plates were coated overnight at $4{ }^{\circ} \mathrm{C}$ with $50 \mu \mathrm{l}$ of EPG at $1 \mu \mathrm{g} / \mathrm{ml}$ in borate saline buffer prior to the assay.

Dot-blot analysis. Dot-blotting was performed as outlined in Pratt et al. (31). Samples containing EPG consisted of growth medium taken directly from shake culture flasks.

Western blot analysis. Western blot analysis was performed according to the method of Towbin et al. (39) with nitrocellulose membranes.

Detection of EPG in $C$. sativus-infected barley leaf segments. Segments $(1 \mathrm{~cm})$ of 10 -day-old leaves of $H$. vulgare cv. Golden Promise were placed on the surface of $1.5 \%$ (wt/vol) noble agar in plastic petri dishes. Spores of C. sativus SB85 (18) were applied to the surface of leaf segments with a sterile camel-hair brush, as described by Clay et al. (13), after which the plates were sealed with wax film (Parafilm) and incubated at $30^{\circ} \mathrm{C}$. At $18 \mathrm{~h}$ postinoculation, a time point at which infection was well established, five infected leaf segments were disrupted by grinding in a groundglass tissue homogenizer with $0.5 \mathrm{ml}$ of $50 \mathrm{mM}$ sodium acetate $(\mathrm{pH} 5.0)$ at $4^{\circ} \mathrm{C}$. Homogenate was filtered through a $0.22-\mu \mathrm{m}$ cellulose acetate syringe filter and frozen until use.

Manipulation of plant material for microscopy. Inoculated/ infected barley leaf samples for microscopy were produced as described above. Uninfected leaf samples for electron microscopy were obtained by punching 1-mm-diameter plugs from 10-day-old leaves of greenhouse-grown $H$. vulgare cv. Golden Promise with a stainless-steel canula. The plugs were expelled from the canula by forcing fixative (described below) from an attached syringe through the canula. To obtain samples of inoculated/infected material for electron microscopy, leaf sections were inoculated, and plugs were removed from the leaf sections as described above. Subsequent processing of tissue plugs for electron microscopy is described below.

Epidermal layers removed from barley coleoptiles provided a monolayer of cells that could be viewed by epifluorescence microscopy without the interference of autofluorescence from chloroplasts within underlying mesophyll cells, allowing a clear view of epidermal cell walls during fungal penetration. For light microscopy, coleoptiles were excised by the method of Bushnell et al. (10), floated on dilute salts solution, inoculated with spores by the brush method, and incubated as described above. After $18 \mathrm{~h}$ of incubation, material was processed for light microscopy as outlined below.

Electron microscopy. Material was processed as outlined in Clay et al. (13), with flat embedding (33) in Quetol 651 (Ted Pella Inc., Redding, CA) and polymerization at $60^{\circ} \mathrm{C}$ for $24 \mathrm{~h}$ or by the progressive lowering of temperature (PLT) technique (42), using LR White resin (Ted Pella) and low-temperature UV polymerization at $-20^{\circ} \mathrm{C}(30)$. Differential interference contrast (DIC) and 
epifluorescence microscopy were used to locate infection sites at different stages of penetration in resin-embedded material for ultramicrotomy. Although all infected plant material was fixed for microscopy at $18 \mathrm{~h}$ postinoculation, germination of the fungal spores was staggered temporally, providing a continuum of penetration stages from very early to advanced on any given portion of inoculated epidermal tissue. Very early penetration sites, at which penetration pegs had only slightly entered the host, were located in LR White resin blocks by observing small autofluorescent halos (blue excitation, Zeiss [Oberkochen, Germany] blue filter set 487909) that persisted during tissue processing. In these sites, well-defined penetration points could be observed because the overlying appressoria had been sheared away from the host surface during processing. Penetration sites containing intact appressoria with intercellular hyphal elements were located in Quetol 651 resin-embedded material by DIC microscopy. A minimum of six specimens was examined for each stage of penetration represented. Sections were cut with a diamond knife on an RMC (Tucson, AZ) ultramicrotome, picked up on gilded slot grids, and placed on Formvar bridges (36) to dry. After cytochemical labeling, the sections were poststained with $4 \%$ uranyl acetate and lead citrate (34) and observed with a Zeiss EM902 electron microscope.

Light microscopy. Light-level microscopy utilized an Axioskop microscope (Zeiss) equipped with DIC and epifluorescence optics. Epifluorescence microscopy with Calcofluor staining was used to visualize the fungus on host tissue. Staining was accomplished by immersion of inoculated leaf segments or coleoptiles in a Calcofluor solution of $10 \mathrm{mg} / \mathrm{ml}$ for $5 \mathrm{~s}$, followed by a water rinse and subsequent wet mounting. Epifluorescence of Calcofluor-stained specimens was viewed through Zeiss UV filter set 487902.

Cytochemistry. Cellulase gold conjugate was made and applied according to published methods $(7,8)$, with sections from material embedded in both LR White and Quetol 651. Purified cellulase complex from Trichoderma reesei was obtained from Worthington Enzymes (Freehold, NJ). Substrate specificity of the cellulase complex was evaluated by assaying for generation of reducing sugar units, using the colorimetric method of Lever (27), which uses PAHBAH as a chromogenic reagent and various substrates, including tamarind xyloglucan (obtained from M. Pauly, Complex Carbohydrate Research Center, Athens, GA), oat spelt xylan (Sigma), and wheat arabinoxylan (Megazyme, Sydney, Australia). Experimental controls for the specificity of cellulase gold labeling included overnight preincubation of sections with nonconjugated enzyme $(1 \mathrm{mg} / \mathrm{ml})$ and competitive inhibition of the cellulase probe with carboxymethyl cellulose (CMC) $(1 \mathrm{mg} / \mathrm{ml})$ during section labeling.

Immunogold localization of PGA and esterified pectin on LR White sections was accomplished as outlined by Beesley (5), with MAbs JIM 5 and JIM 7 (24), respectively. Anti-rat gold conjugate was made according to Freshour et al. (19), using goat anti-rat immunoglobulin G (IgG) obtained from Sigma. Experimental controls for specificity of immunocytochemical labeling included omission of the primary antibodies, preincubation of primary antibodies with ligand (citrus pectin for JIM 7 and PGA for JIM 5), and substitution of primary antibodies with an extraneous rat MAb.

An alternative method for localizing PGA was accomplished with purified $C$. sativus EPG as a primary cytochemical reagent, followed by a gold-labeled MAb specific for the enzyme. Specifically, sections of host cell walls processed and embedded in Quetol 651 were floated on purified $C$. sativus EPG in $50 \mathrm{mM}$ sodium acetate buffer at $\mathrm{pH} 5.0(\approx 1 \mathrm{mg} / \mathrm{ml})$ for $30 \mathrm{~min}$, blocked with skim milk (5) for $10 \mathrm{~min}$, and exposed for 30-min to the EPGspecific MAb EPG-4 and, finally, to a secondary antibody (goat anti-mouse IgG, whole molecule; Sigma) coupled to gold by the procedure described in Freshour et al. (19). The antibodies were applied, and the buffers were used as outlined for immunolabeling in Beesley (5), with minor modification. We apply the term EMSIL (enzyme-mediated substrate immunolocalization) to this indirect localization technique. Control measures applied to EMSIL included omission of the enzyme, omission of the primary antibody, and substitution of the primary antibody with an extraneous murine MAb.

\section{RESULTS}

Enzyme production and purification. The profile of the initial cation-exchange chromatographic separation of the protein recovered from the growth medium exhibited a major peak at $47 \%$ (vol/ vol) buffer B (Fig. 1A) and was identified as EPG by the PAHBAH and substrate-gel assays. A second cation-exchange chromatographic separation of the pooled EPG-containing fractions produced a single peak with a small shoulder at $47 \%$ (vol/vol) buffer B (Fig. 1B). EPG-positive fractions contained small quantities of 12 - and $58-\mathrm{kDa}$ contaminants that were removed by microdialysis and an additional chromatographic separation (as outlined above), after which the preparations were homogeneous for EPG, as determined by SDS-PAGE (Fig. 2).

Enzyme characterization. Molecular mass of $C$. sativus EPG, as determined by MALDI-TOF-MS analysis of two separate preparations, was $34 \mathrm{kDa} \pm 0.1 \%$ (Fig. 3). The isoelectric point was

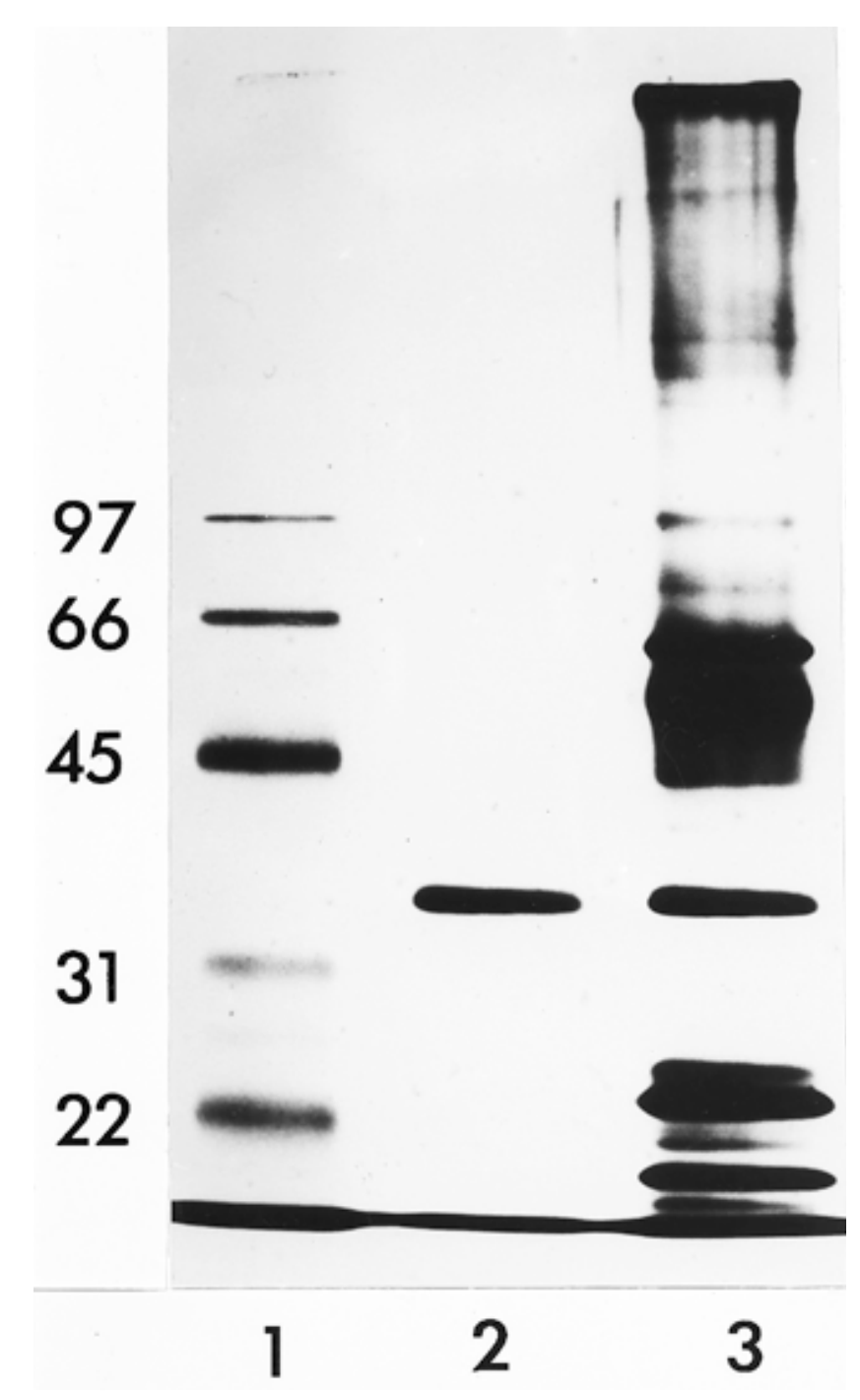

Fig. 2. Sodium dodecyl sulfate-polyacrylamide gel electrophoresis of lane 1, molecular weight markers; lane 2, purified Cochliobolus sativus endopolygalacturonase (EPG); and lane 3, profile of protein recovered by ethanol precipitation from $C$. sativus growth medium containing citrus pectin as the sole carbon source. This represents the mixture from which the EPG in lane 2 was purified. 
estimated to be in the range of 9.0 to 9.5 . The N-terminal sequence of the enzyme was AVTTFTDAATAIKNKASXTN, with $\mathrm{X}$ most likely representing cysteine. Sequence comparison (Fig. 4) revealed that the $\mathrm{N}$ terminus contained a 14 amino acid region (TFTDAATAIKNKAS) identical to the same region within the amino acid sequence for EPG from $C$. carbonum.

Chemical and enzymatic methods of deglycosylation failed to decrease the apparent molecular weight of the EPG, as shown by SDS-PAGE, indicating a lack of glycosylation. The lack of glycosylation was supported by the failure of a variety of lectin-DIG conjugates to detect any carbohydrate moieties at the position of the EPG band on an electrophoretic transfer blot of the crude fungal extract (data not shown). Controls run with fungal EPGs ( $F u$ sarium moniliforme and Aspergillus niger) known to be glycosylated gave the expected positive responses. Finally, the close match between the mass determined by MALDI-TOF-MS and the mass deduced from the nucleotide sequence of the gene for the $C$. carbonum EPG further supported to the lack of glycosylation.

PGIP inhibition. The ability of PGIPs from bean, pear, and tomato to inhibit the EPG of $C$. sativus was investigated. A series of assays in which $C$. sativus EPG was titrated with increasing concentrations of the PGIPs indicated that each of the three PGIPs was able to inhibit more than $95 \%$ of the activity of the $C$. sativus EPG (data not shown).

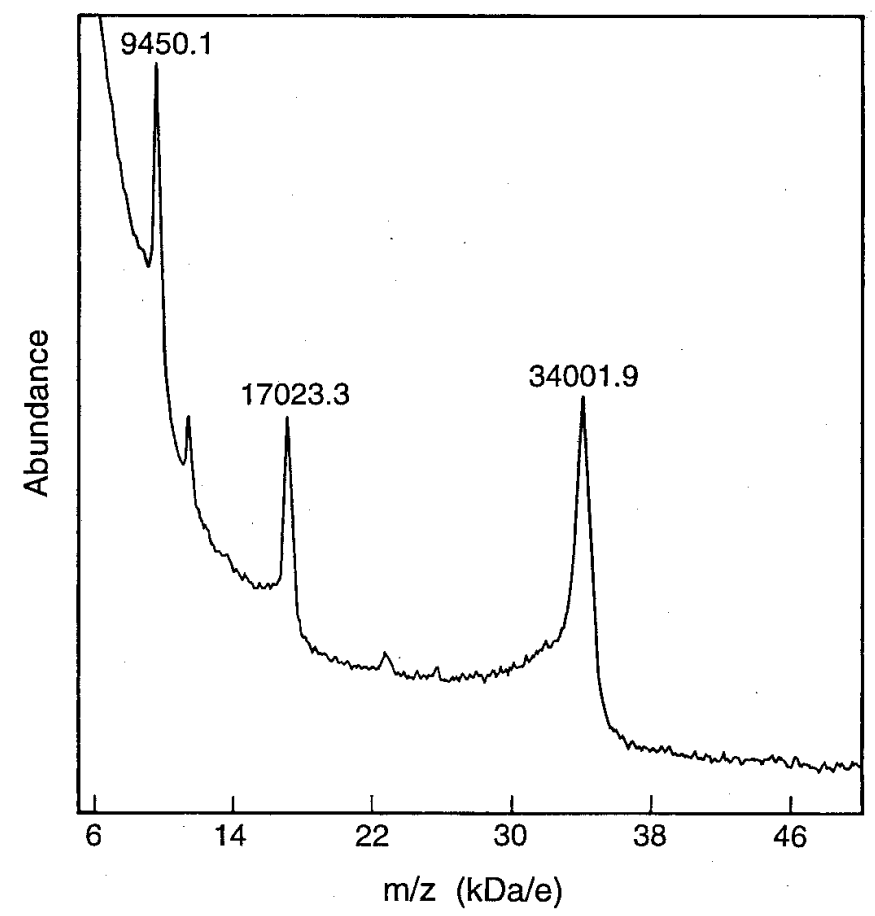

Fig. 3. Representative matrix-assisted laser desorption/ionization time-of-flight mass spectrometry of endopolygalacturonase, demonstrating a molecular mass of $34 \mathrm{kDa} \pm 0.1 \%$ for the enzyme. Peaks shown are for the quadruply, doubly, and singly charged species, respectively.

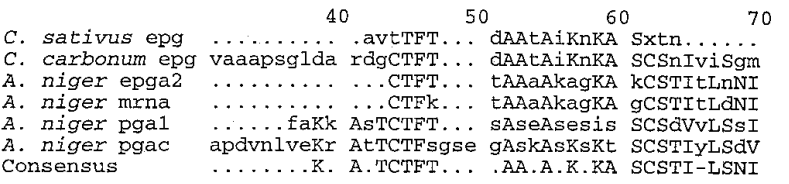

Fig. 4. Portion of a sequence comparison of fungal pectinases, as generated by the Pretty section of the University of Wisconsin Genetic Computer Group sequence analysis software package (17), representing positions 31 to 70 of the sequence alignment. The 20-residue sequence for Cochliobolus sativus endopolygalacturonase represents the $\mathrm{N}$-terminus sequence determined during the current study.
Immunology. From a pool of 14 clones positive for native EPG in ELISA, Western blot analysis identified two clones that produced antibodies that recognized EPG after electrophoresis under denaturing conditions (Fig. 5, lanes 1 and 2). These two MAbs, designated EPG-4 and EPG-5, were both of the $\mathrm{IgG}_{1}$ class, with kappa light chains. The high titer and specificity characteristic of EPG-4 led to its exclusive use in further studies. Dot-blot analysis revealed that EPGs from six $C$. sativus strains were recognized by EPG-4 (data not shown). Preliminary attempts to localize EPG in infected tissue with EPG-4 were not successful; further attempts at in situ localization were not made.

Western blot analysis of the total protein profiles from $C$. $s a$ tivus-infected barley leaf pieces detected a single 34-kDa band positive for EPG with the MAb EPG-4 (Fig. 5, lane 3) at $18 \mathrm{~h}$ postinoculation. Infection was well established at this time, with the infected tissue exhibiting obvious water-soaked mottling. The uninfected leaf profile probed as a control for possible plant PG cross-reactivity was totally devoid of signal and, thus, is not presented. Infected plant tissue beyond the $18 \mathrm{~h}$ time point quickly became macerated and necrotic, such that the leaf pieces could no longer be removed intact from the agar surface, making it impossible to extend a time-course screen for the presence of EPG beyond $18 \mathrm{~h}$.

Microscopy and cytochemistry. The EMSIL obtained with the purified EPG on transverse sections of Quetol 651-embedded barley leaf epidermal cells taken perpendicular to the long axis of the cells and anticlinal to the leaf surface revealed that PGA, the substrate for EPG, was localized primarily in the cell corners and middle lamella of these cells (Fig. 6). JIM 5 immunogold labeling of similar plant material exhibited a labeling distribution for PGA identical to that obtained by EPG-EMSIL (Fig. 6, insets A and B).

The site of penetration of the barley epidermis by $C$. sativus consistently was centered over anticlinal junctures of epidermal

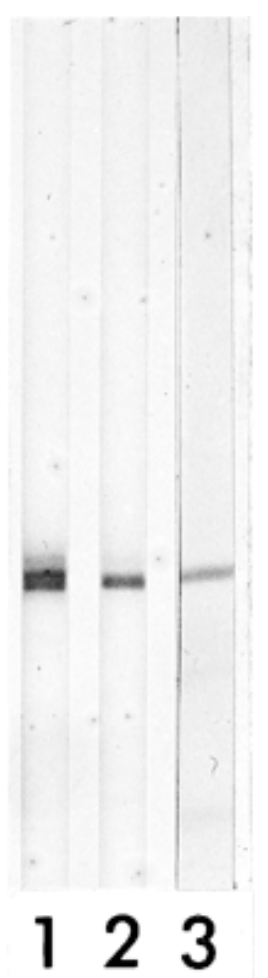

Fig. 5. Western blot analysis of Cochliobolus sativus endopolygalacturonase (EPG). Lane 1, Total protein profile of $C$. sativus culture supernatant probed with monoclonal antibody (MAb) EPG-4. Lane 2, Total protein profile of $C$. sativus culture supernatant probed with MAb EPG-5. Lane 3, Total protein profile from $C$. sativus-infected barley leaf pieces, $18 \mathrm{~h}$ after inoculation, probed with MAb EPG-4. An uninfected leaf profile probed as a control for possible plant polygalacturonase cross-reactivity was totally devoid of signal and is not shown. 
cell walls (Fig. 7A and B). Epifluorescence microscopy visualized an autofluorescent host response $(28,38)$ surrounding the site of early penetration (Fig. 7A), followed by a pronounced separation of the primary walls of the epidermal cells along the middle lamella during intercellular hyphal ingress (Fig. 7C and D). At the focal plane presented in Figure $7 \mathrm{C}$, the penetration peg often could be seen during the early stage of infection. Although the host cell walls in Figure 7C and D were displaced considerably from their original positions, they appeared to be intact and continuous with the unaffected portions of the host cell wall.

Cytochemical localization by JIM 5 of PGA in LR White serial sections of healthy cell corners and adjoining periclinal cell walls again revealed that the polymer was localized almost exclusively in the cell corners and middle lamella (Fig. 8A). JIM 7 localized esterified pectin in the cell corners, middle lamella, and outer portions of the epidermal cell walls adjacent to the cuticle (Fig. 8B). JIM 7 labeling adjacent to the cuticle decreased in density with increasing proximity to the plasma membrane, leaving a relatively unlabeled band of wall adjacent to the plasma membrane (Fig. $8 \mathrm{~B})$. Labeling with the cellulase-gold probe was greatest in the portion of the cell wall that was not labeled for esterified pectin, and the density of the label decreased with increasing proximity to the cuticular layer (Fig. 8C). Labeling with cellulase gold was extremely light in the cell corners and middle lamella (Fig. 8C).

LR White sections taken through very early penetration sites, from which appressoria and penetration pegs had been mechanically removed during processing, invariably revealed cavities extending into the cell corner (Fig. 9A and B). These cavities were characterized by a scalloped margin indicative of enzymatic degradation and were lined with a layer of slightly electron-opaque fibrillar material that was thickest at the bottom of the cavities (Fig. 9B) and apparently had filled the gap between the original position of the penetration peg and the unaltered host cell wall matrix (Fig. 9B and inset). The cavities typically extended underneath remnants of a persistent host-surface layer surrounding the point of penetration (Fig. 9A and B). No compression or other deformation of the cell wall matrix surrounding the position of the penetration peg was apparent, aside from a slight turning-in of the persistent surface layer (Fig. 9A and B). JIM 5 labeling of PGA in the region of these early penetration sites occurred in the unaltered wall region adjacent to the scalloped margin of the degradation zone but did not significantly label the electron-opaque fibrillar material bordering the scalloped margin of the penetration cavity (Fig. 9A and B). Sections through more deeply penetrated cell corners also exhibited narrow zones of apparent degradation surrounding the fungal elements (Fig. 10). The cell wall matrix within these zones was less electron opaque than the surrounding wall matrix. In Figure 10, the wall matrix outside the narrow zone of lower electron density appeared disrupted and separated in some areas, yet the layer of cell wall continuous with the periclinal walls of the epidermal cells appeared relatively unaltered.

Advanced stages of penetration were characterized by a total replacement of the cell corner matrix by an enlarged hyphal element situated between thin, separated host cell walls that labeled strongly with the cellulase gold probe (Fig. 11A and B) when embedded in Quetol 651. Eventually, penetration of host epidermal

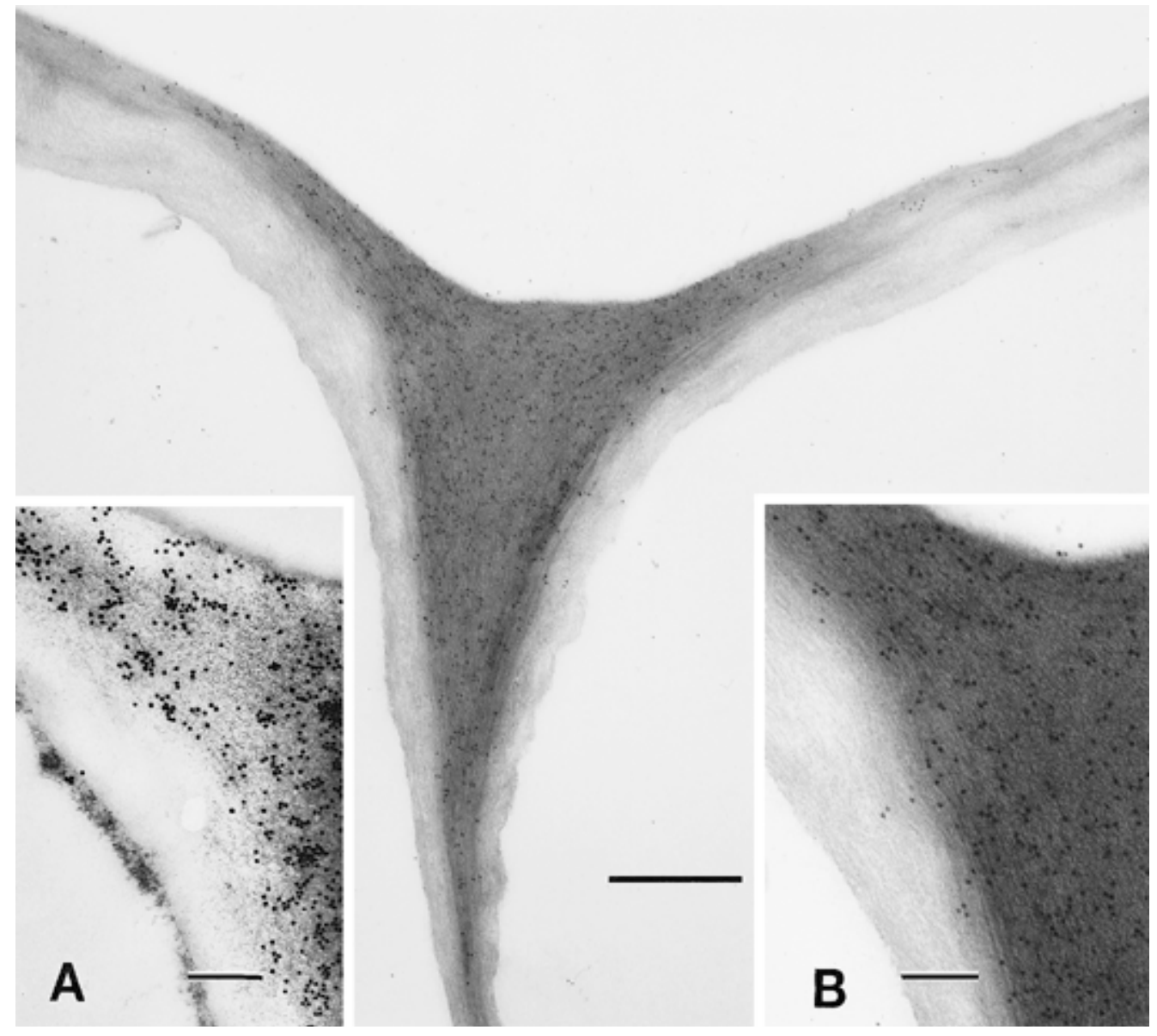

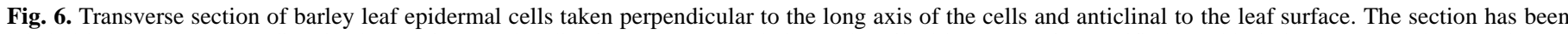

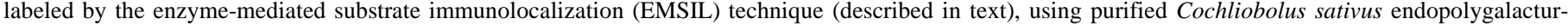

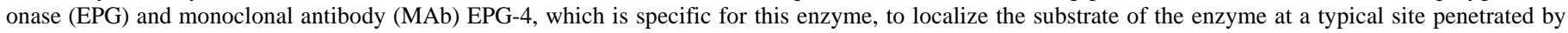

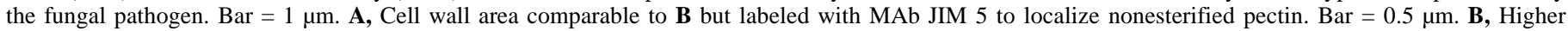
magnification of a portion of Figure 7. Bar $=0.5 \mu \mathrm{m}$. 
cells occurred by penetration of these thin cell walls (Fig. 11B and inset). In Figure 11B and the inset, a septum and associated Woronin body can be seen within the penetrating hyphal element at the point where the host cell wall was penetrated. The Woronin body appeared to occlude the septal pore. This condition resembles observations made during an in vitro microscopic study (13) in which plugged septae were observed in $C$. sativus penetrating the dialysis membrane.

Cytochemical controls. Cellulase gold labeling of thin sections was reduced dramatically by pretreatment of sections with unconjugated cellulase or by competition of conjugated enzyme with CMC during labeling. Preincubation of JIM 5 and JIM 7 with PGA or citrus pectin, respectively, dramatically reduced specific labeling on thin sections. Control experiments for EPG-EMSIL labeling specificity resulted in total elimination of labeling.

Purity and hydrolytic specificity of the cellulase preparation. SDS-PAGE of the cellulase enzyme preparation used to localize $\beta$-1,4-D-glucans, and apparently $\beta$-1,4-D-xylans, revealed four distinct bands ranging in molecular mass from 40 to $75 \mathrm{kDa}$ (data not shown). The enzyme complex liberated reducing sugar when incubated with tamarind xyloglucan, wheat arabinoxylan, and oat spelt xylan (data not shown).
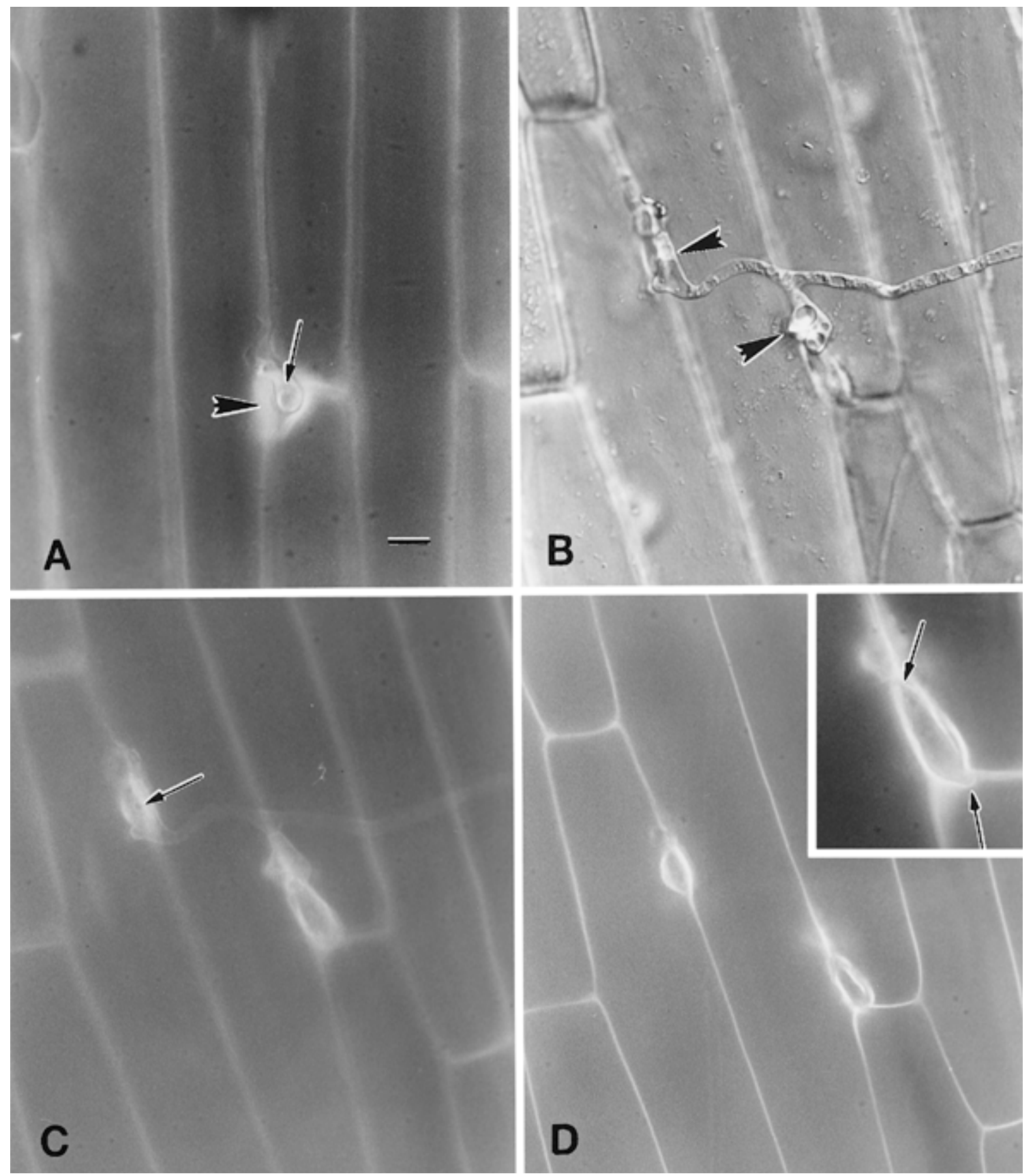

Fig. 7. A, Barley coleoptile epidermal cell layer penetrated by Cochliobolus sativus. A halo (arrowhead) surrounds the fungal appressorium (arrow). The micrograph is a double exposure of epifluorescence from two excitation wavelengths (UV and blue light, described in text) to simultaneously visualize the autofluorescence of both the host cell walls and the host reaction to the initial penetration event, as well as Calcofluor staining of the fungus. Bar $=10 \mu \mathrm{m}$. B, Differential interference contrast micrograph of a barley coleoptile epidermal layer penetrated at two sites by $C$. sativus (arrowheads). Same magnification as A. C, Same specimen as in A at a lower focal plane and viewed by autofluorescence and Calcofluor staining with UV excitation. The penetration peg (arrow) is visible at one site on this focal plane. Same magnification as A. D, Same specimen shown in $\mathbf{B}$ and $\mathbf{C}$ at a lower focal plane. The epidermal cell walls of the host are separated along the middle lamella at both penetration sites by the ingress and expansion of hyphal elements of the pathogen. Same magnification as $\mathbf{A}$. Inset: The separated primary walls of the host epidermal cells appear continuous with the unseparated regions of the walls (arrows). Inset magnification at $2 \times$ that of $\mathbf{D}$. 


\section{DISCUSSION}

We purified and characterized an EPG from $C$. sativus. This EPG was used to generate antibodies for use in cytochemical studies, including a novel method of localizing PGA polymers in the cell walls of barley leaves. The findings indicate that the EPG isolated from C. sativus SB85 is very similar to the EPG isolated and purified by Walton and Cervone (41) from C. carbonum. The molecu-
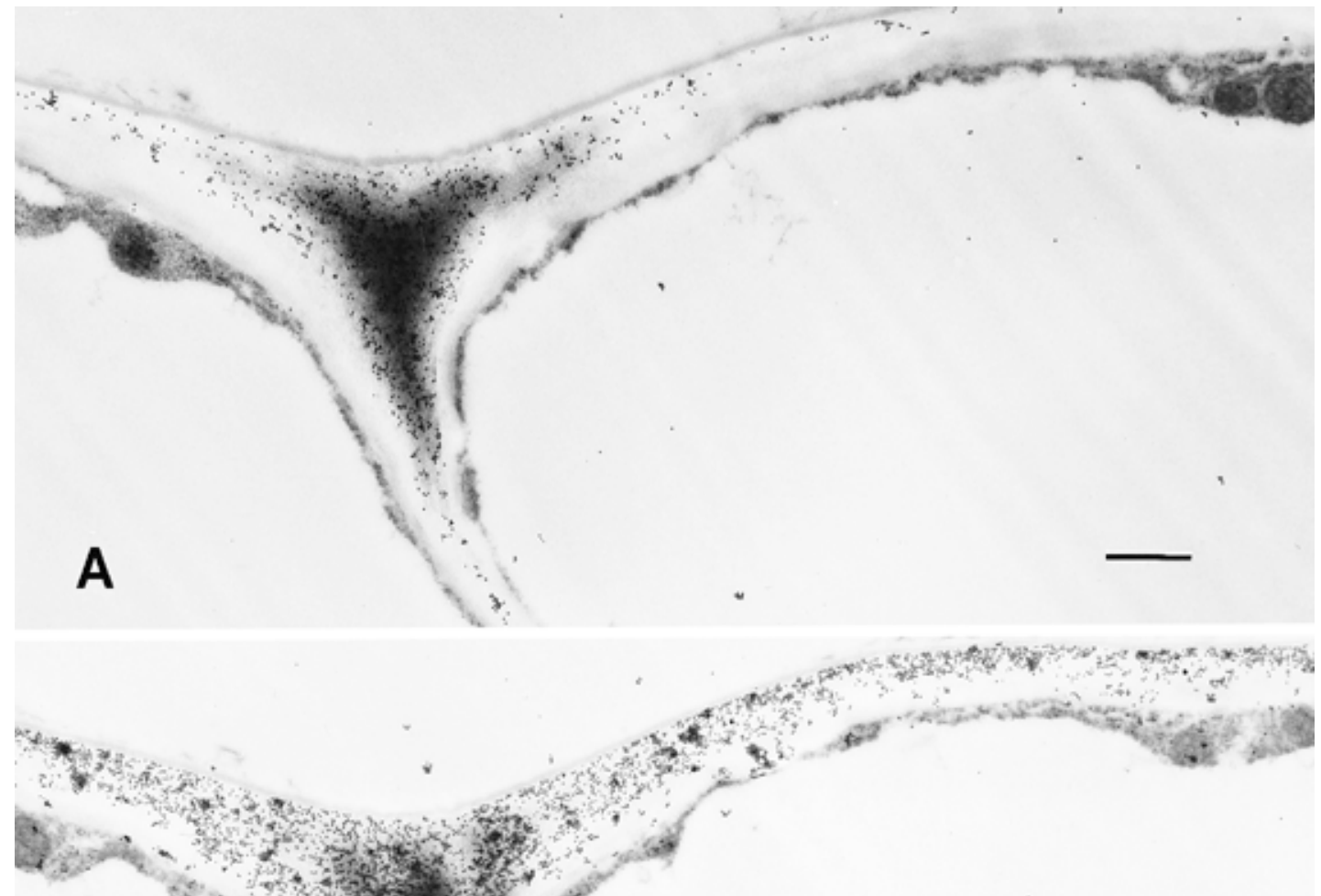

B

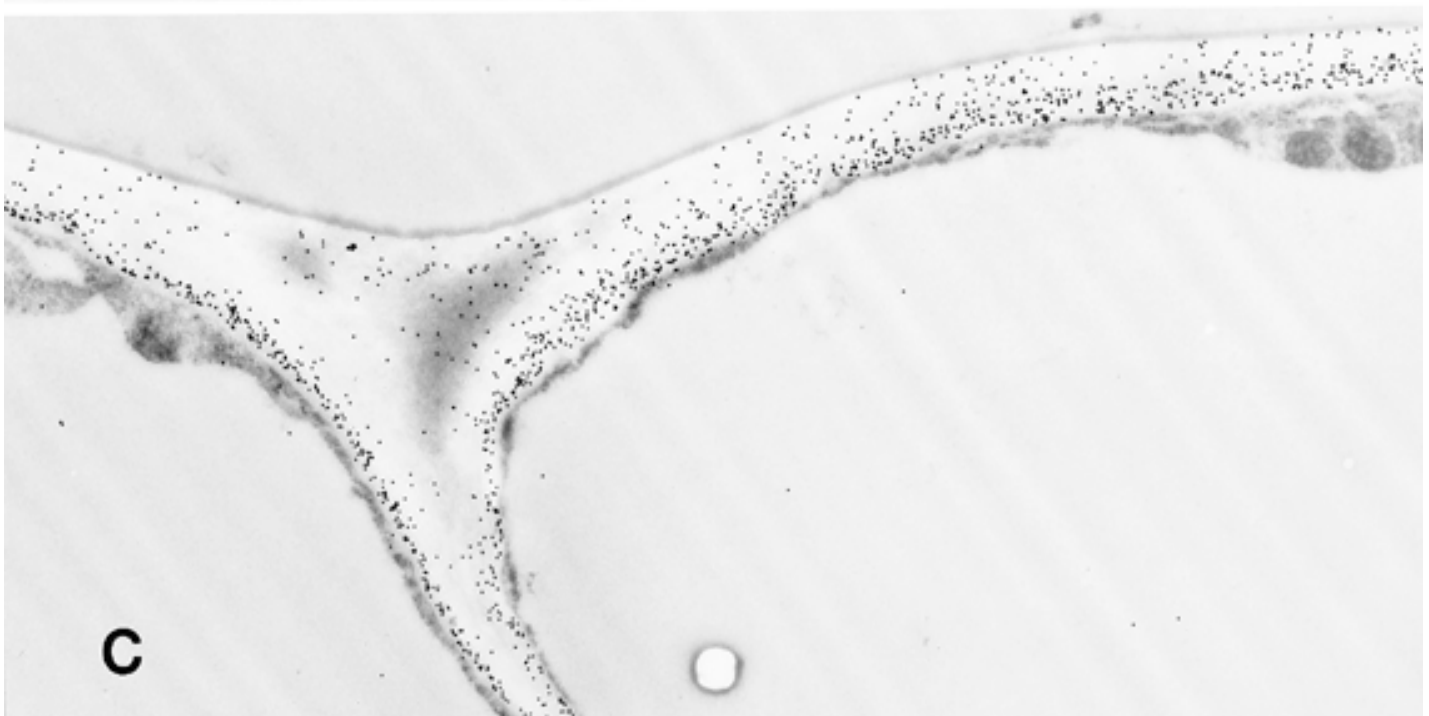

Fig. 8. Skipped serial sections through an anticlinal cell wall junction between two healthy barley leaf epidermal cells embedded in LR White resin and gold labeled for cell wall polysaccharides. This junction is representative of a typical penetration site for Cochliobolus sativus. A, Monoclonal antibody (MAb) JIM 5 immunogold labeling of polygalacturonic acid. B, MAb JIM 7 immunogold labeling of esterified pectin. C, Cellulase gold labeling of cellulose and possibly some hemicellulosic polymers. The locations of the labeling in $\mathbf{A}$ and $\mathbf{C}$ are almost mutually exclusive. $\mathbf{B a r}=1 \mu \mathrm{m}$. 
lar mass of the $C$. sativus $\mathrm{EPG}(34 \mathrm{kDa})$ matches, within the mass accuracy of the spectrometer, the predicted mass of the $C$. carbonum EPG (33,992 Da) based on the sequence of the PGN1 gene (37). The N-terminus sequence of the two EPGs showed only minor differences (Fig. 4). Further, the DNA sequence of a 550-bp fragment of an EPG gene from $C$. sativus Sandoz 87 coding for the central portion of the protein, including a region homologous to the intron present in the sequence for PGN1, exhibited greater than $90 \%$ sequence homology with PGN1 (J. Enkerli, personal communication). These results indicate that the EPGs from C. sativus SB85 and C. carbonum are products of closely related genes.

The inhibition of $C$. sativus EPG by bean PGIP was not surprising, because the EPG from $C$. carbonum already had proven susceptible to this inhibitory protein (41). Prior to the observed inhibition of $C$. sativus EPG by pear and tomato PGIPs, only an EPG from Botrytis cinerea had proven susceptible to inhibition by these PGIPs. Interestingly, the lack of glycosylation on $C$. sativus EPG suggests that the carbohydrate moieties found on most fungal EPGs are not critical to their binding for inhibition by PGIP nor are they critical to their glycosidase activities. It has been speculated that glycosylation may be important in binding EPG to PGIP, because the glycosylated fungal EPGs are inhibited by $P$. vulgaris PGIP, whereas bacterial EPGs are not glycosylated and inhibited by PGIP. $C$. sativus provides the first direct evidence that the carbohydrate moieties of fungal EPGs are not involved in inhibition of the enzyme by PGIP.

Antibodies specific for $C$. sativus EPG were generated successfully, although only 2 (EPG-4 and EPG-5) of the 14 antibodies of the native protein identified by ELISA were able to recognize the denatured protein in Western blot analysis. An antibody having affinity to both the native and denatured protein would be applicable to a broader range of immunological studies than those that recognize only the native protein. The high titer and specificity of EPG-4 led to its selection for further experimentation. The cross-reactivity of EPG-4 for EPGs of different $C$. sativus strains may facilitate future study of the EPGs from these strains. Given the successful recognition by EPG-4 of the EPG bound to PGA in thin sections used during the EMSIL technique, it would seem that the epitope for EPG-4 is not a portion of the binding site of the enzyme nor is such recognition sterically hindered by association of the enzyme with its substrate.

Two avenues for implicating $C$. sativus EPG activity during the infection process include (i) detection of the enzyme in infected tissue and (ii) detection of homogalacturonan degradation in host cell walls. Detection of the enzyme would seem most direct, but enzyme detection does not necessarily constitute localization of active hydrolysis; it is possible for EPG to be produced constitutively yet be inhibited or inactivated by plant proteins or other aspects of the apoplastic environment, such that substrate hydrolysis does not occur. Thus, the enzyme could be present and detectable yet not actually participatory in the penetration process. Therefore, our main effort toward implicating EPG hydrolysis during penetration involved visualization of homogalacturonan loss from the penetration site.

Using JIM 5, we cytochemically visualized the loss of PGA from the infection site, as discussed below, and, by application of the EMSIL technique, confirmed that the cell wall component that labeled with JIM 5, in fact, did colocalize with the substrate recognized by purified $C$. sativus EPG. Still, if homogalacturonan is degraded during penetration, pectin-degrading enzymes should be present and detectable. Our preliminary attempts to localize the EPG in situ at the electron microscope level were unsuccessful. Subsequent ELISA studies revealed that recognition of EPG by EPG-4 was reduced significantly (greater than 50\% reduction in ELISA absorbance values) by exposure of the EPG to $1 \%$ (vol/ vol) glutaraldehyde for $1 \mathrm{~h}$. Thus, other fixatives or procedures, such as the PLT technique $(35,42)$, may be required to immobilize this extracellular enzyme in host tissue if in situ immunolocalization of the enzyme is attempted with this antibody. We successfully detected EPG by Western blot analysis of protein extracts
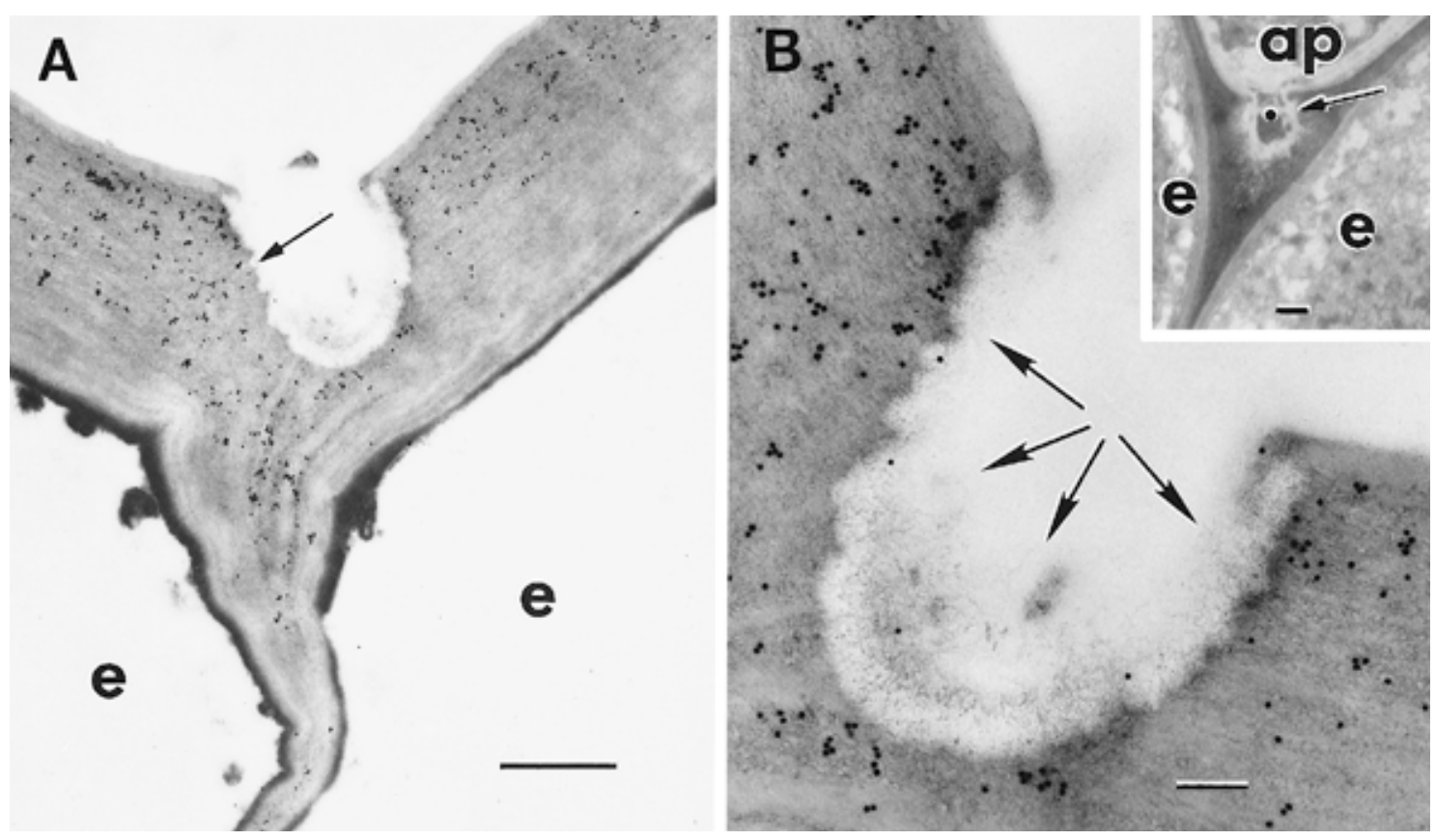

Fig. 9. A, Section through an anticlinal cell wall junction between two barley leaf epidermal cells (e) embedded in LR White resin and immunolabeled with monoclonal antibody JIM 5 to localize polygalacturonic acid (PGA). The junction is in the early stage of penetration by Cochliobolus sativus. The appressorium with penetration peg was sheared from the epidermal surface during specimen processing for electron microscopy. A cavity produced by the fungal penetration peg extends into the cell corner and is delineated from the host cell wall matrix by a scalloped margin (arrow), suggesting enzymatic degradation of the cell wall matrix. Immunolabeling of PGA occurred in the cell corner around and up to the scalloped cavity. Bar $=1 \mu \mathrm{m}$. B, Higher magnification of the cavity shown in A. Fibrillar material (arrows) that was not significantly labeled by JIM 5 borders the scalloped margin of the cavity. Bar $=0.25 \mu \mathrm{m}$. Inset: Section through barley leaf epidermal cells (e) in a stage of penetration comparable to that seen in $\mathbf{A}$ and $\mathbf{B}$ but embedded in Quetol 651 resin. Appressorium (ap) and penetration peg $(\bullet)$ are present. A zone of altered cell corner matrix (arrow) surrounds the penetration peg. Bar $=1 \mu \mathrm{m}$. 
from host tissue $18 \mathrm{~h}$ after inoculation with the pathogen. At this time point, many fungal germlings had successfully penetrated the host tissue, causing some associated cell death (12). This detection of EPG in infected tissue demonstrated that the presence of the enzyme was coincident with the infection process.

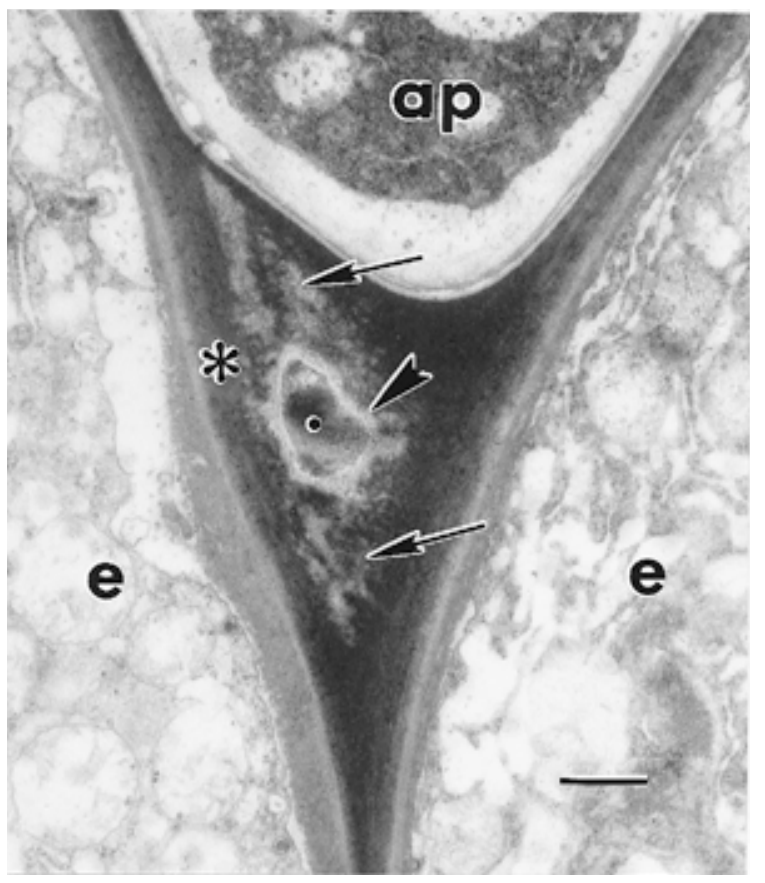

Fig. 10. Epidermal cell (e) wall juncture with fungal appressorium (ap) and penetration hypha $(\bullet)$ inserted into the cell corner from a point out of the plane of section. The peg is surrounded by an apparent degradation zone (arrowhead) that is less electron opaque than the surrounding wall matrix. Although the wall matrix outside the less electron-opaque zone appears disrupted and separated in some areas (arrows), the layer of cell wall continuous with the periclinal walls of the epidermal cells appears relatively unaltered $(*)$. Bar $=0.5 \mu \mathrm{m}$.
The preferential formation of appressoria of Cochliobolus sp. within the grooves formed by the anticlinal junction of host plant epidermal cell walls has been well documented $(13,22,23)$. The observation of irregular or scalloped zones of cell wall matrix disruption surrounding $C$. sativus penetration pegs at these sites strongly suggests the involvement of CWDEs during the initial penetration of barley by $C$. sativus. If enzymatic degradation does occur during early penetration, the immunolocalization of PGA by both JIM 5 and EPG-EMSIL, exclusively in the areas targeted by the pathogen, suggests the involvement of EPG in the degradation process. This is supported by the detection of $C$. sativus EPG in infected barley leaf tissue by Western blot analysis. The relative abundance of a variety of polysaccharides present in host cell walls often has been considered indicative of the likelihood of participation of various CWDEs in pathogenesis. On this basis, one might suspect minimal contribution from pectin-degrading enzymes during pathogenesis in these plants, because pectic polysaccharides constitute only a small proportion of the total polysaccharide compliment of the gramineous monocot cell wall. However, this concept does not consider the relative abundance of pectic polymers in strategic locations within the plant tissues. Although compositional analysis revealed that galacturonosyl acid residues comprise only $10 \%$ of the polysaccharide content of young barley leaves and coleoptiles (R. P. Clay, unpublished data), the high concentration of pectic polysaccharides in the vicinity of the typical penetration site for C. sativus is demonstrated by the immunolocalization data. Yadav (43) concluded that $C$. sativus germlings require an exogenous energy source for successful penetration. Given the concentration of pectic cell wall polymers at the site of penetration, perhaps these polysaccharides are utilized by the fungus during penetration. This possibility is supported by the finding that pectin-degrading enzymes are the first to be produced during degradation of wheat straw by $C$. sativus and also that a significant increase in fungal biomass occurs before xylanase or cellulase activity can be detected (9). Thus, pectic compounds possibly represent a more readily available source of energy for the pathogen than cellulosic or hemicellulosic polymers.
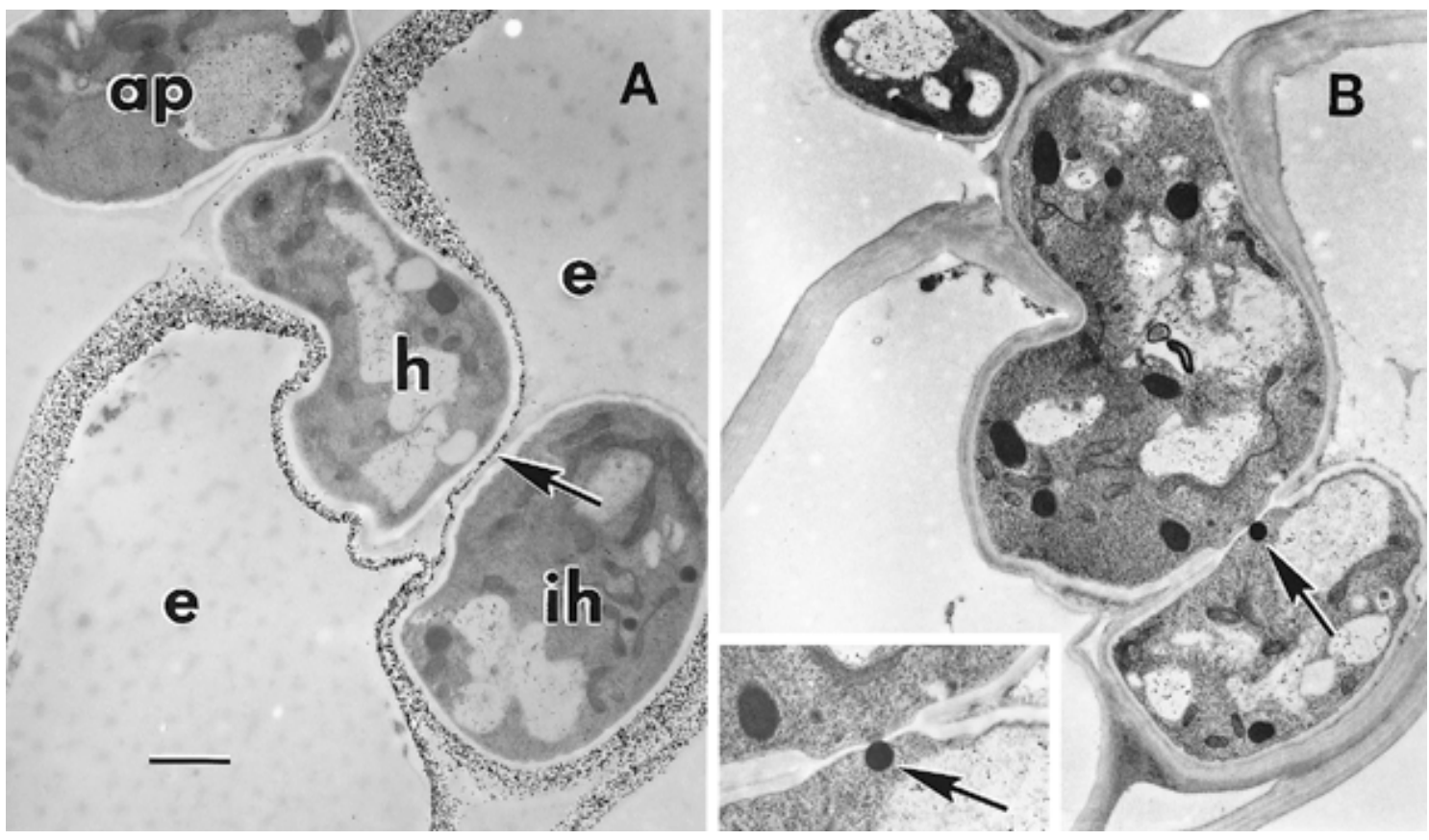

Fig. 11. A, Advanced stage of barley leaf penetration by Cochliobolus sativus. The pathogen has penetrated the anticlinal cell wall junction between two host epidermal cells (e). The fungal appressorium (ap) is visible above the cell corner. The host cell corner matrix is displaced by an enlarged hyphal element (h) situated between the thin cell walls of the host epidermal cells. The host epidermal cell walls are densely labeled with a cellulase gold probe. The point of host epidermal cell penetration is not visible in this section but occurred at the point indicated by the arrow. An intercellular hyphal element (ih) is present within the penetrated host cell. $\mathrm{Bar}=1 \mu \mathrm{m}$. B, Skipped serial section of the specimen in A showing the point of host cell penetration. A septum formed within the penetrating hyphal element at the point where it breached the host cell wall. A Woronin body (arrow) is associated with the septum and appears to occlude the septal pore. Same magnification as in A. Inset: Enlargement of the septum in B, showing the Woronin body (arrow) associated with the septal pore. Magnification is $1.5 \times$ that of $\mathbf{B}$. 
If this conclusion is correct, the fungus may have adapted to target the cell corners during initial penetration because of the concentration of readily available carbohydrate in the form of pectic polymers located there, as opposed to the cellulose/hemicellulose matrix that would be encountered during direct entry through the periclinal cell walls of epidermal cells. It is possible that after establishment of a successful infection, the fungus may not rely on the degradation of pectic polymers to continually gain access to plant tissues and extract energy, but it would seem more likely for available pectin to be exhausted before the cellulose/ hemicellulose matrix is attacked in a given tissue region. The observation that hyphae from $C$. sativus continue to preferentially traverse host tissues via the middle lamella after penetration of host tissue (R. P. Clay, unpublished data) supports this supposition. Another possible adaptive advantage of preferential entry by way of pectin-rich regions of host tissue concerns the requirement of some fungal pathogens of a period of high humidity for successful penetration; the pectin-rich cell corners may offer a path of less resistance to pathogen entry than cellulosic layers, allowing quicker establishment of infection during transitory periods of sufficient humidity.

The specificity of the labeling obtained with the probe made with the cellulase complex from $T$. reese $i$ is uncertain based on the results of the reducing sugar assays. It is reasonable to accept that cellulose was labeled, but if and what hemicellulosic polymers also may have been labeled is questionable. According to the manufacturer, this enzyme preparation is a true cellulase complex able to convert crystalline, amorphous, and chemically derived celluloses to glucose and contains at least three distinct enzymatic components, including $\beta$-1,4-D-glucan cellobiohydrolase, endoglucanase, and exoglucanase. Because the closely related $T$. viride cellulase complex contains endoglucanases that are active against xyloglucan $(6,40)$ and a $\beta$-glucosidase able to degrade xylans $(6)$, these enzymatic activities also may be present in the gold probe made with $T$. reese $i$ cellulase; the results of the reducing sugar assays support this possibility. Also, the additional protein band detected after SDS-PAGE of the cellulase preparation could represent a contaminating xylanase. Assessment of the purity of the substrates utilized in the PAHBAH assays for cellulase substrate specificity was beyond the scope of this study. Therefore, it also is possible that reducing sugar liberated from these substrates may have been due to the presence of residual $\beta$-1,4-D-glucan polymers. However, because the cellulase-gold probe did not label significantly in the vicinity of the initial penetration site, uncertainty about the substrate specificity of the probe does not invalidate evidence for the involvement of EPG during early penetration.

The composition and origin of the fibrillar material present in the early penetration cavity remains unknown. Given the lack of labeling by the cellulase gold probe in the cell corners and the lack of labeling of fibrillar material by either JIM 5 or JIM 7, it apparently does not contain PGA, esterified pectin, or cellulose. Therefore, if the material is of plant origin, some possibilities for its composition include hemicellulosic polymer, rhamnogalacturonan II, protein, cutin, and lignin. Another possibility is that the material is an extracellular matrix produced by the fungus.

A thorough understanding of the function of CWDEs during host penetration depends on knowledge of the location and identity of the polymeric substrates for the CWDEs. The identity and location of these substrates may be determined cytochemically at the ultrastructural level by probing with either antibodies specific for the substrate polymers or with substrate-specific enzymes coupled to electron-dense markers. Unfortunately, antibodies specific for cell wall polysaccharides are difficult to produce and often are not specific for the desired polysaccharide (32). Also, some CWDEs cannot be coupled successfully to markers or cannot be purified in sufficient quantity for direct probe production. The EMSIL technique developed during this study could prove useful in these cases. For example, EMSIL would allow for localization of a particular cell wall substrate for which antibodies cannot be generated due to lack of immunogenicity of the substrate. It also could be used in cases in which enzymes specific to the substrate cannot be labeled for use in enzyme-gold localizations due to instability of the enzyme, inactivity of gold-bound enzyme, lack of enzyme purity, size of the enzyme molecule below the threshold size for conjugation, etc. EMSIL also would be appropriate with an enzyme that is extremely difficult or costly to purify, rendering it unfeasible to obtain quantities of purified enzyme sufficient for coupling directly to gold.

If an experiment similar to the $C$. carbonum EPG gene knock out by Scott-Craig et al. (37) is performed with $C$. sativus, wherein a mutant strain of $C$. sativus unable to degrade PGA subsequently is virulent on barley, it would be interesting to compare the mode of penetration of the mutant to that of the wild-type. Such investigations may help determine the feasibility of disabling critical enzymes as a potential disease control measure.

\section{ACKNOWLEDGMENTS}

This work was supported by funding from Sandoz Ltd., and in part by Department of Energy (DOE) grant DE-FG02-96ER20221 and the DOEfunded (DE-FG05-93ER20097) Center for Plant and Microbial Complex Carbohydrates. We thank the Molecular Genetics Instrumentation Facility (University of Georgia) for amino acid sequencing, composition analysis, and MAP synthesis; the Monoclonal Antibody Facility (University of Georgia), including L. Aron and H. Chun Huang, for services during production of the monoclonal antibodies; K. Kolli for MALDI-TOF-MS molecular weight determination; R. Prade for assistance with the computer alignment of the amino acid sequence; J. Dean for assistance with viscometry; T. G. Fetch, Jr. for supplying strain SB85; and K. Roberts for supplying JIM 5 and JIM 7.

\section{LITERATURE CITED}

1. Almin, K. E., and Eriksson K.-E. 1967. Enzymatic degradation of polymers. I. Viscometric method for the determination of enzymic activity. Biochim. Biophys. Acta 139:238-247.

2. Apel, P. C., Panaccione, D. G., Holden, F. R., and Walton, J. D. 1993. Cloning and targeted gene disruption of $X Y L 1$, a $\beta 1$,4-xylanase gene from the maize pathogen Cochliobolus carbonum. Mol. Plant-Microbe Interact. 6:467-473.

3. Baker, C. J., Whalen, C. H., and Bateman, D. F. 1977. Xylanase from Trichoderma pseudokoningii: Purification, characterization, and effects on isolated plant cell walls. Phytopathology 67:1250-1258.

4. Bateman, D. F., and Basham, H. G. 1976. Degradation of plant cell walls and membranes by microbial enzymes. Pages 316-355 in: Encyclopedia of Plant Physiology, vol. 4. R. Heitefuss and P. H. Williams, eds. SpringerVerlag, New York.

5. Beesley, J. E. 1989. Colloidal Gold: A New Perspective for Cytochemical Marking. Oxford University Press, Kent, England.

6. Beldman, G., Searle-Van Leeuwen, M. F., Rombouts, F. M., and Voragen A. G. J. 1985. The cellulase of Trichoderma viride: Purification, characterization and comparison of all detectable endoglucanases, exoglucanases and $\beta$-glucosidases. Eur. J. Biochem. 146:301-308.

7. Bendayan, M. 1989. The enzyme-gold approach: A review. Pages 118145 in: Colloidal Gold: Principles, Methods and Applications. Vol. 2. M. A. Hayat, ed. Academic Press Inc., New York.

8. Berg, R. H., Erdos, G. W., Gritzali, M., and Brown, R. D. 1988. Enzymegold affinity labeling of cellulose. J. Electron. Microsc. Technol. 8:371379 .

9. Boothby, D., and Magreola, N. O. 1984. Production of polysaccharide degrading enzymes by Cochliobolus sativus and Fusarium culmorum grown in liquid culture. Trans. Br. Mycol. Soc. 83:275-280.

10. Bushnell, W. R., Dueck, J., and Rowell, J. B. 1967. Living haustoria and hyphae of Erysiphe graminis f. sp. hordei with intact and partially dissected host cells of Hordeum vulgare. Can. J. Bot. 45:1719-1732.

11. Cervone, F., De Lorenzo, G., Degra, L., Salvi, G., and Bergami, M. 1987. Purification and characterization of a polygalacturonase-inhibiting protein from Phaseolus vulgaris L. Plant Physiol. 85:631-637.

12. Clay, R. P. 1996. Studies of the mechanism of host penetration during the infection of Hordeum vulgare by Cochliobolus sativus. Ph.D. dissertation. University of Georgia, Athens.

13. Clay, R. P., Enkerli, J., and Fuller, M. S. 1994. Induction and formation 
of Cochliobolus sativus appressoria. Protoplasma 178:34-47.

14. Collimer, A., Reid, J., and Mount, M. S. 1988. Assay methods for pectic enzymes. Methods Enzymol. 161:329-335.

15. Cooper, M. R. 1983. The mechanisms and significance of enzymatic degradation of host cell walls by parasites. Pages 101-135 in: Biochemical Plant Pathology. J. A. Callow, ed. John Wiley \& Sons Ltd., New York.

16. Côtè, F., and Hahn, M. G. 1994. Oligosaccharins: Structures and signal transduction. Plant Mol. Biol. 26:1379-1411.

17. Devereux, J., Haeberli, P., and Smithies, O. 1984. A comprehensive set of sequence analysis programs for the VAX. Nucleic Acid Res. 12:387-395.

18. Fetch, T. G., Jr., Steffenson, B. J., and Franckowiak, J. D. 1992. Pathotypes of Cochliobolus sativus on barley. (Abstr.) Phytopathology 82:1101.

19. Freshour, G., Clay, R. P., Fuller, M. S., Albershiem, P., Darvill, A. G., and Hahn, M. G. 1996. Developmental and tissue-specific structural alterations of the cell-wall polysaccharides of Arabidopsis thaliana roots. Plant Physiol. 110:1413-1429.

20. Goding, J. W. 1986. Monoclonal Antibodies: Principles and Practice. 2nd ed. Academic Press, San Diego, CA.

21. Hahn, M. G., Bucheli, P., Cervone, F., Doares, S. H., O'Neill, R. A., Darvill, A., and Albersheim, P. 1989. Roles of cell wall constituents in plant-pathogen interactions. Pages 131-181 in: Plant Microbe Interactions, vol. 4. E. Nester and T. Kosuge, eds. McGraw-Hill Publishing Co., New York.

22. Hau, F. C., and Rush, M. C. 1979. Leaf surface interactions between Cochliobolus miyabeanus and susceptible and resistant rice cultivars. (Abstr.) Phytopathology 69:527.

23. Huang, H. C., and Tinline, R. D. 1976. Histology of Cochliobolus sativus infection in subcrown internodes of wheat and barley. Can. J. Bot. 54:1344-1354.

24. Knox, J. P., Linstead, P. J., King, J., Cooper, C., and Roberts, K. 1990. Pectin esterification is spatially regulated both within cell walls and between developing tissues of root apices. Planta 181:512-521.

25. Köhler, G., and Milstein, C. 1976. Derivation of specific antibody-producing tissue culture and tumor cell lines by cell fusion. Eur. J. Immunol. 6:511-519.

26. Laemmli, U. K. 1970. Cleavage of structural proteins during the assembly of the head of bacteriophage T4. Nature (Lond.) 227:680-685.

27. Lever, M. 1972. A new reaction for colorimetric determination of carbohydrates. Anal. Biochem. 47:273-279.

28. Mayama, S., and Shishiyama, J. 1978. Localized accumulation of fluorescent and u.v. absorbing compounds at penetration sites in barley leaves infected with Erysiphe graminis hordei. Physiol. Plant Pathol. 13:347-354.

29. Misaghi, I. J. 1982. The role of pathogen-produced cell-wall-degrading enzymes in pathogenesis. Pages 17-34 in: Physiology and Biochemistry of Plant Pathogen Interactions. Plenum Press, New York.
30. Polak, J. A., and Varndell, I. M. 1984. Immunolabelling for Electron Microscopy. Elsevier Science Publishing Co., New York.

31. Pratt, L. H., McCurdy, D. W., Shimazaki, Y., and Cordonnier, M.-M. 1986. Immunodetection of phytochrome: Immunocytochemistry, immunoblotting and immunoquantitation. Pages 50-74 in: Modern Methods of Plant Analysis. New Series, vol. 4. H. F. Linskens and J. F. Jakcons, eds. SpringerVerlag, New York.

32. Pullman, J., Bucheli, E., Swain, M. J., Dunning, N., Albersheim, P., Darvill, A. G., and Hahn, M. G. 1994. Generation of monoclonal antibodies against a plant cell-wall polysaccharide. Plant Physiol. 104:699-710.

33. Reymond, O. L., and Pickett-Heaps, J. 1983. A routine flat embedding method for electron microscopy of microorganisms allowing selection and precisely oriented sectioning of single cells by light microscopy. J. Microsc. 130:79-84.

34. Reynolds, E. S. 1963. The use of lead citrate at high $\mathrm{pH}$ as an electron opaque stain in electron microscopy. J. Cell Biol. 17:208-212.

35. Roth, J., Bendayan, M., Carlemalm, E., Villiger, W., and Garavito, M. 1981. Enhancement of structural preservation and immunocytochemical staining in low temperature embedded pancreatic tissue. J. Histochem. Cytochem. 29:663-671.

36. Rowley, J. C., III, and Moran, D. T. 1975. A simple procedure for mounting wrinkle-free sections on Formvar coated slot grids. Ultramicroscopy 1:151-155.

37. Scott-Craig, J. S., Panaccione, D. G., Cervone, F., and Walton, J. D. 1990. Endopolygalacturonase is not required for pathogenicity of Cochliobolus carbonum on maize. Plant Cell 2:1191-1200.

38. Shiraishi, T., Yamaoka, N., and Kunoh, H. 1989. Association between increased phenylalanine ammonia-lyase and cinnamic acid synthesis and the induction of temporary inaccessibility caused by Erysiphe graminis primary germ-tube penetration of the barley leaf. Physiol. Mol. Plant Pathol. 34:75-83.

39. Towbin, H., Staehelin, T., and Gordon, J. 1979. Electrophoretic transfer of proteins from polyacrylamide gels to nitrocellulose sheets: Procedure and some applications. Proc. Natl. Acad. Sci. USA 76:4350-4354.

40. Vincken, J.-P., Beldman, G., and Voragen, A. G. J. 1994. The effect of xyloglucans on the degradation of cell-wall-embedded cellulose by the combined action of cellobiohydrolase and endoglucanases from Trichoderma viride. Plant Physiol. 104:99-107.

41. Walton, J. D., and Cervone, F. 1990. Endopolygalacturonase from the maize pathogen Cochliobolus carbonum. Physiol. Mol. Plant Pathol. 36:351-359.

42. Wells, B. 1985. Low temperature box and tissue handling device for embedding biological tissue for immunostaining in electron microscopy. Micron Microsc. Acta 16:49-53.

43. Yadav, B. S. 1981. Behaviour of Cochliobolus sativus during its infection of wheat leaves. Aust. J. Bot. 29:71-79. 